\section{Steady-state heat rejection rates for a coaxial borehole heat exchanger during passive and active cooling determined with the novel step thermal response test method}

\author{
Tomislav Kurevija'; Marija Macenić' ${ }^{2}$ Kristina Strpić3 \\ Faculty of Mining, Geology and Petroleum Engineering; 10000 Zagreb, Croatia \\ ${ }^{1}$ Associate Professor ${ }^{2}$ Researching Assistant ${ }^{3}$ Researching Assistant
}

The Mining-Geology-Petroleum Engineering Bulletin UDC: 622.1

DOI: 10.17794/rgn.2018.2.6

Original scientific paper

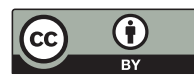

\begin{abstract}
:
Classic and extended step thermal response test were conducted on three different locations in Zagreb. Measurements with the classical thermal response test were used to determine thermogeological properties of the ground and thermal resistance of the borehole for each location. Different values of thermal conductivity are the result of differences in the geological profile and depth of the sites. In addition, experimental research of the steady-state thermal response step test (SSTRST) was carried out to determine heat rejection rates for passive and active cooling in a steady state regime. Results showed that the heat rejection rate is only between 8-11 W/m, which indicates that the coaxial system is not suitable for passive cooling demands. Furthermore, the heat pump in passive cooling mode uses an additional plate heat exchanger which causes heat losses and additional temperature rise of the working fluid by approximately $1.5^{\circ} \mathrm{C}$. Therefore, the steady-state rejection rate for passive cooling is even lower for a real case project. The coaxial heat exchanger should always be designed for an active cooling regime with an operation of a heat pump compressor in a classical vapour compression refrigeration cycle.
\end{abstract}

Keywords

shallow geothermal energy, thermogeology, borehole heat exchanger, ground source heat pump

\section{Introduction}

A geothermal borehole exchange system functionally depends on many thermogeological, techno-economical and climatic parameters. Due to the exponential increase of the number of installed geothermal heat pump systems over the last decade, a lot of software for borehole field design has been developed, mostly based on the model of heat transfer in a homogeneous conductive infinite media. Therefore, accurate determination of the initial static temperature and the thermal conductivity coefficient of the ground, along with the optimally defined heat extraction and rejection rates, are preconditioned for a properly designed long-term heat exchange system. The Classical Thermal Response Test (TRT) is a widely used method today to define these basic ground thermogeological parameters. The method is based on observing the evolution of the working borehole fluid temperature during the applied constant heat rate for an acceptable minimum period of $48 \mathrm{hr}$ (Zhang et al. 2011).

However, the increasing use of shallow geothermal systems is based on passive cooling in the summer months. The basic difference between passive and active

Corresponding author: Tomislav Kurevija

tkurevi@rgn.hr cooling by a geothermal heat pump implies the use of different temperature regimes and technical equipment. In passive cooling, the heat pump only redirects the flow from the borehole exchanger to a separate plate heat exchanger and directly exchanges the heat energy between the colder borehole fluid and the warmer fluid from the consumer's distribution system. In order for the cooling of the building to be satisfactory, a temperature regime of $16 / 19^{\circ} \mathrm{C}$ or $18 / 21{ }^{\circ} \mathrm{C}$ has to be distributed within the building.

Exact determination of heat rejection potential of the geothermal coaxial heat exchangers in the passive cooling regime has not been adequately covered in scientific and technical literature thus far. One of the potential solutions to this problem is the application of the novel method presented in this paper, the steady-state thermal response step test (SSTRST).

\section{Methods}

The thermal response test (TRT) is a well-known method in thermogeology for determining thermal conductivity of the ground. The interpretation of the obtained data is focused on determining the temperature response of the fluid, circulating through the heat exchanger, in a function of time and constant heat flow rejection. 


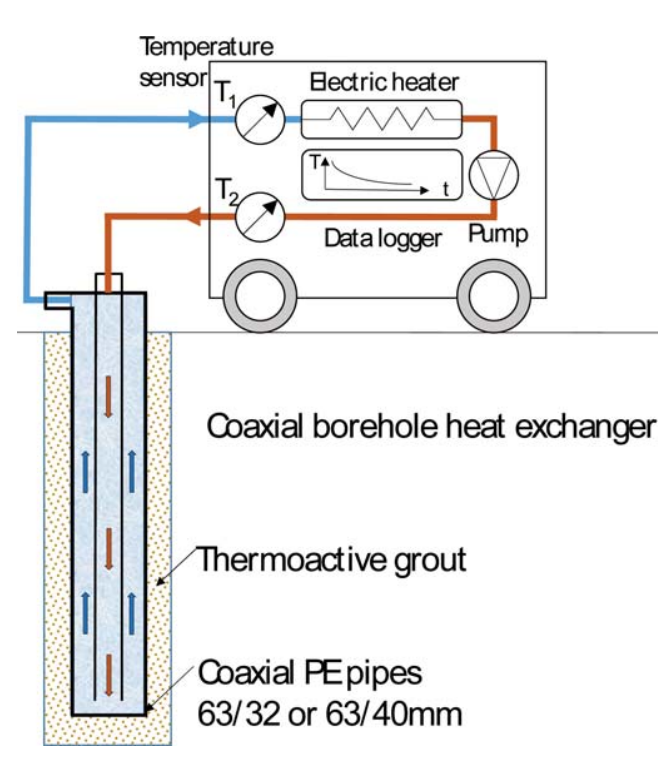

Figure 1: Thermal Response Test (TRT) equipment

This method is equivalent to the flow test found in well testing in petroleum engineering. The similarity in the mathematical solutions for radial fluid flow in a porous media (petroleum engineering, hydrogeology) and heat conduction in solids according to Fourier's law is well known (Matthews and Russell, 1967; Carslaw and Jaeger, 1959; Narasimhan 1999; Sass and Lehr, 2011). The solution of the diffusivity partial equation which describes radial heat transfer is named the line source theory. The radial heat transfer, valid for infinite, homogeneous and isotropic conductive media is written as diffusivity in Equation 1 (Lee, 1982):

$$
\frac{\partial^{2} T}{\partial r^{2}}+\frac{1}{r} \frac{\partial T}{\partial r}=\frac{1}{\alpha} \frac{\partial T}{\partial t}
$$

Where the constant term $\alpha$ is thermal diffusivity and it is described as $\frac{\lambda}{c_{p} \rho}$.

The borehole heat exchanger is assumed to be situated in an infinite medium for which the general analytical solution for temperature field at a certain radius and time, in the case of performing the TR test (heat rejected to the ground) is shown in Equation 2:

$$
T(r, t)=T_{i}+\frac{q^{\prime}}{2 \pi \lambda}\left[\frac{1}{2} E i\left(\frac{r^{2}}{4 \alpha t}\right)\right]
$$

Where Ei represents the exponential integral with the following solution (3):

$$
E i(x)=\int_{x}^{\infty} \frac{e^{-u}}{u} d u
$$

When $\mathrm{x}<0.01$, the exponential integral can be simplified as (4):

$$
E i(x) \cong-\ln \left(e^{\gamma} x\right) \cong \ln \left(\frac{1}{x}\right)-0,5772
$$

Considering the simplification above and when $\frac{4 \alpha t}{r^{2}}>100$, Equation 2 for heat rejection into the ground can be written as (5):

$$
\begin{gathered}
T(r, t)=T_{i}-\frac{q^{\prime}}{4 \pi \lambda} \ln \left(\frac{e^{\gamma} r^{2}}{4 \alpha t}\right)=T_{i}+\frac{q^{\prime}}{4 \pi \lambda}\left(\ln \frac{4 \alpha t}{r^{2}}-0,5772\right)= \\
=T_{i}+\frac{q^{\prime}}{4 \pi \lambda}\left(\ln \frac{\alpha t}{r^{2}}+0,80907\right)
\end{gathered}
$$

This solution represents an approximation for an infinite medium and assumes that the borehole radius is negligible compared to depth. When compared to calculations with practical values of normal borehole radius, it gives almost identical results.

The equation for line source theory (see Equation 5) can be used as an estimation of heat rejection into the ground via the borehole heat exchanger (Gehlin, 2002). The method for determining thermal conductivity, from data obtained in the TRT during a semi steady-state period, is graphoanalyitical and it consists of determining the slope of the average measured temperature versus the natural log of time curve and correlation (6):

$$
T(t)=k \times \ln (t)+m ; k=\frac{q^{\prime}}{4 \pi \lambda}
$$

Where $k$ is the slope and $m$ is the intercept of the yaxis.

In the petroleum engineering well testing procedure, skin is a dimensionless factor defined as a near-borehole damaged zone, where permeability of the rock decreases. Analogously, in thermogeology, the skin represents local thermal resistance to heat flow and can be expressed as (7):

$$
\Delta T_{\text {skin }}=s\left(\frac{q^{\prime}}{2 \pi \lambda}\right)=R_{b} \times q^{\prime}
$$

The third term $\left(R_{b} \times q^{\prime}\right)$ is more commonly used in thermogeology to describe the effect of the different thermal conductivity of cement and pipe material. By using thermally active cement, the skin effect can be reduced, since its thermal conductivity is somewhat higher than the widely used bentonite based grout.

When the expression for skin effect is added into Equation 5, the obtained expression is (8):

$$
T=T_{i}-\frac{q}{4 \pi \lambda}\left(\ln \left(\frac{e^{\gamma} r_{w}^{2}}{4 \alpha t}\right)-2 s\right)
$$

Or when expressing for skin (9):

$$
s=\frac{1}{2} \ln \left(\frac{e^{\gamma} r_{w}^{2}}{4 \alpha t}\right)-\frac{\left(T_{i}-T\right) 2 \pi \lambda}{\bar{q}}
$$

Equations 7 and 9 are used when calculating skin from the measured data obtained from the TRT. It uses average heat rejection rate, $q$ and temperature, $T$, obtained at the end of the measuring period. The theory of infinite line source is an ideal solution in the case when there is no borehole resistance. Therefore, the calculated 


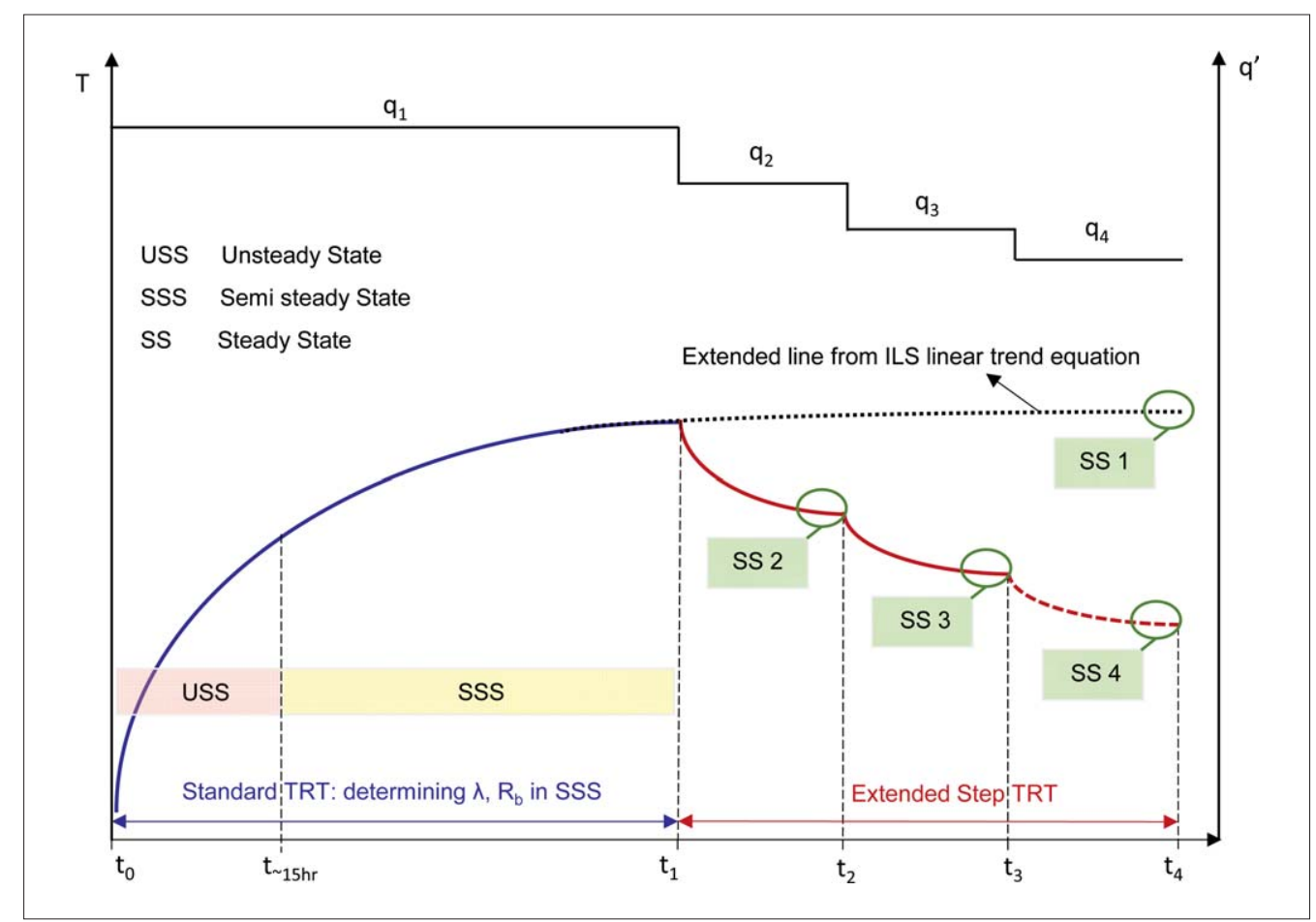

Figure 2: Evolution of the novel Steady-state Thermal Response Step Test

$\Delta \mathrm{T}_{\text {skin }}$ represents the temperature difference needed to overcome borehole resistance to establish heat flow from fluid to the ground and it is added to the ILS solution.

In practice, the heat extraction/rejection rate varies following seasonal change. The multiple flow test from the petroleum well testing technique (Stewart, 2011) is analogous to the novel steady-state thermal response step test (SSTRST) in thermogeology. The solution gives the evolution of the temperature using infinite line source theory and a mathematical technique known as principle of superposition. With the superposition principle, it is possible to predict the temperature for any given heat flow rate (see Figure 2).

In SSTRST, the first step period is performed with the highest heat rejection rate. For every following step, the heat rate decreases. Such a step test is used to define optimal working conditions of the exchanger. In the case of three heat flow rates, temperature behaviour for the heat rejection case will be (10):

First step: $t_{0} \leq t \leq t_{1}$

$$
\Delta T(t)=T_{i}+\frac{q_{1}^{\prime}}{2 \pi \lambda} \Delta t_{D}(t)+\Delta T_{\text {skin } 1}
$$

The second term from above the equation represents a temperature increase from heat rejection at the first period of the test. After the first period is over, in time $t_{1}$, heat rejection is decreased to a quantity of $q_{2}(11)$ :

Second step: $t_{1} \leq t_{2}$

$$
\Delta T(t)=T_{i}+\frac{q_{1}{ }^{\prime}}{2 \pi \lambda} \Delta t_{D}(t)+\frac{\left(q_{2}{ }^{\prime}-q_{1}{ }^{\prime}\right)}{2 \pi \lambda} \Delta t_{D}\left(t-t_{1}\right)+\Delta T_{\text {skin } 2}
$$

At the end of second period, there is another heat rate decrease to a quantity of $q_{3}$ (12):

Third step: $t_{1} \leq t_{2} \leq t_{3}$

$$
\begin{aligned}
\Delta T(t) & =T_{i}+\frac{q_{1}{ }^{\prime}}{2 \pi \lambda} \Delta t_{D}(t)+\frac{\left(q_{2}{ }^{\prime}-q_{1}{ }^{\prime}\right)}{2 \pi \lambda} \Delta t_{D}\left(t_{1}\right)+ \\
& +\frac{\left(q_{3}{ }^{\prime}-q_{2}{ }^{\prime}\right)}{2 \pi \lambda} \Delta t_{D}\left(t_{2}-t_{1}\right)+\Delta T_{\text {skin } 3}
\end{aligned}
$$

In each of the equations above, $\Delta t_{D}$ is a dimensionless factor which represents the sum of all the terms in the braces in Equation 2 and for the case of heat rejection is (13):

$$
\Delta t_{D}=\frac{1}{2} E i\left(\frac{r_{w}{ }^{2}}{4 \alpha t}\right)
$$

The general term when performing step TRT is (14):

$$
\begin{gathered}
\Delta T(t)=T_{i}+\frac{q_{1}{ }^{\prime}}{2 \pi \lambda} \Delta t_{D}(t)+\frac{\left(q_{2}{ }^{\prime}-q_{1}{ }^{\prime}\right)}{2 \pi \lambda} \Delta t_{D}\left(t_{1}\right)+ \\
+\ldots+\frac{\left(q_{n}{ }^{\prime}-q_{n-1}{ }^{\prime}\right)}{2 \pi \lambda} \Delta t_{D}\left(t-t_{n-1}\right)+\Delta T_{\text {skin } n}
\end{gathered}
$$

It is necessary to add $\Delta T_{\text {skin }}$ of the corresponding period to the equation, with the notion that the value of it must be calculated separately for each period. Therefore, the skin factor must be calculated for each period with the notion that the average heat rate and temperature difference are taken for the period in question. 


\section{Overview of technical and thermogeological design aspects of coaxial geothermal systems - case study}

\subsection{Technical aspects of inclined coaxial heat exchanger system}

The design and execution of inclined coaxial borehole heat exchangers is technically a more demanding process than the classic vertical boreholes with a $2 \mathrm{U}$ pipe loop. During completion works, special attention should be given to the quality of borehole cementing after the insertion of a pipe exchanger. In the case of gravel or sand with high hydraulic conductivity, significant drainage of cement mixtures can occur in the layer, leaving the pipes in the borehole under air pockets or under water. Although water has a higher thermal conductivity than air, it still has much lower thermal conductivity than the surrounding ground and represents significant thermal resistance during heat transfer. In such cases, the cement must be mixed with a smaller amount of bentonite clay to clog the pore space which elevates the borehole thermal resistance value. Also, since the borehole is angled during drilling there is also a common case of collapse of the borehole wall and the inability to perform uniform and quality cementation over the entire length. The existence of this kind of problem is easily determined by TR testing in the segment of defining the equivalent borehole resistance. Typical values of borehole resistance for properly installed coaxial heat exchangers are about $0.130 \mathrm{~m}^{\circ} \mathrm{C} / \mathrm{W}$ for laminar and transient flow, and $0.100 \mathrm{~m}^{\circ} \mathrm{C} / \mathrm{W}$ for preferred turbulent flow. Equivalent borehole thermal resistance includes all local resistances during the transfer of heat from the working fluid to the ground by means of convection and conduction. High values of thermal resistance manifest itself in a very rapid growth of the working fluid temperature in the pipes immediately after the heat pump starts. This is explained by the fact that an increasing temperature difference between the surrounding ground and the working fluid temperature is necessary to achieve an adequate steady-state heat transfer.

Boreholes have a standard diameter of $110 \mathrm{~mm}$, while drilling is performed with special equipment for this kind of system that allows for the setting of the drilling angle from $35^{\circ}$ to $65^{\circ}$ (see Figure 3a). Inclined coaxial exchangers are usually placed inside the polyethylene shaft with a diameter of $1 \mathrm{~m}$ and a depth of $1.5 \mathrm{~m}$ (see Figure $3 \mathbf{b}$ ). The drilling process allows for a maximum angled borehole length of up to $50 \mathrm{~m}$ in all directions. Inclined coaxial borehole heat exchangers are usually made out of an outer polyethylene pipe of $63 \mathrm{~mm}$ with a standard dimension ratio of SDR17 or SDR11, where the inner polyethylene pipe is either $32 \mathrm{~mm}$ or $40 \mathrm{~mm}$ with SDR11. The heat exchanger is hydraulically set in a way that the inner tube serves as a return flow and the annular area functions as a supply flow to the heat pump.

\subsection{Technical aspects of geothermal heat pump system with active and passive cooling option}

The distribution temperature regime for a passive cooling systems (LLT-Leaving load temperature/ELTEntering load temperature) is usually set at $16 / 19{ }^{\circ} \mathrm{C}$ or $18 / 21^{\circ} \mathrm{C}$, depending on the floor, wall or ceiling pipe installations. Considering that the effective ground temperature across the angled coaxial boreholes is $14{ }^{\circ} \mathrm{C}$ for the Zagreb area, the passive cooling option has a very low temperature difference between the geothermal
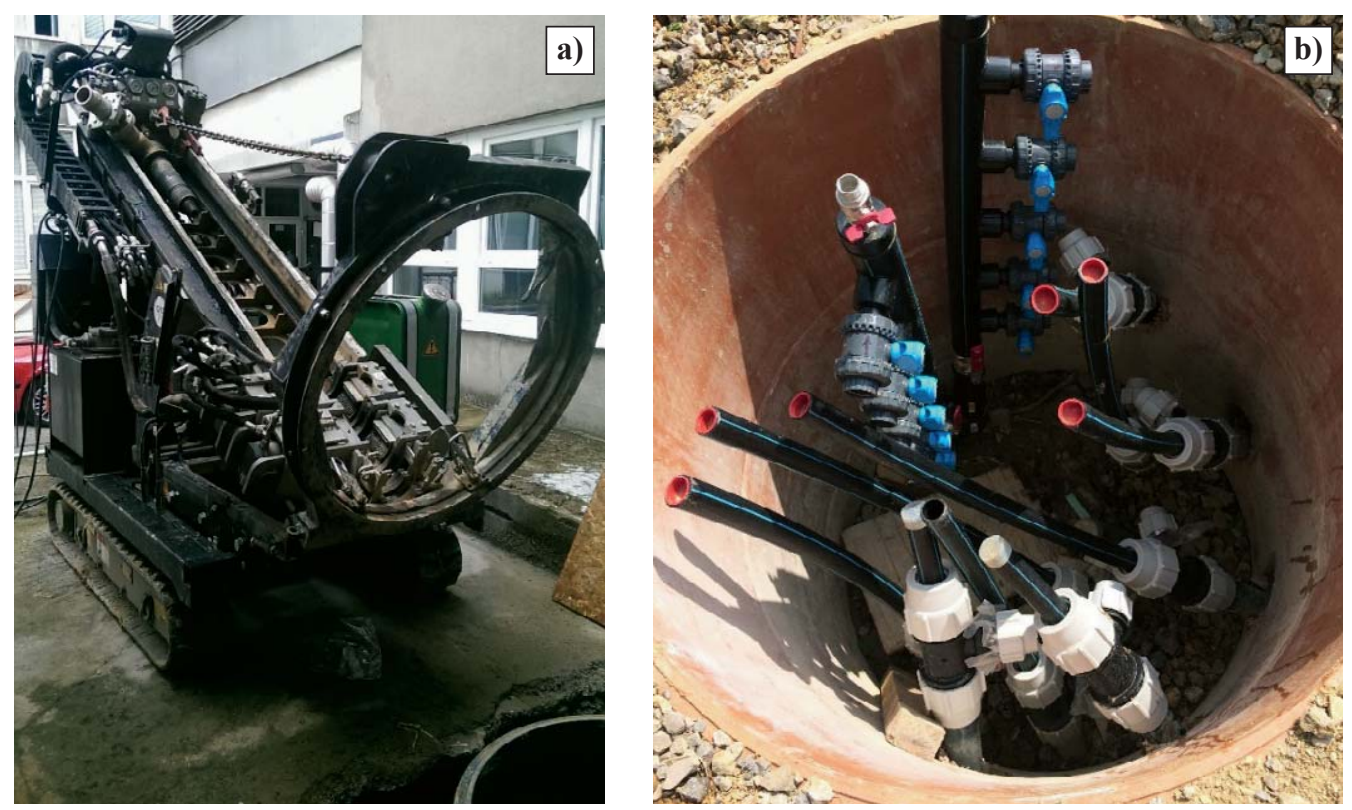

Figure 3: Drilling equipment for an inclined coaxial borehole heat exchanger system (location RGN Faculty) and example of completed shaft with to boreholes (TVK family house) 


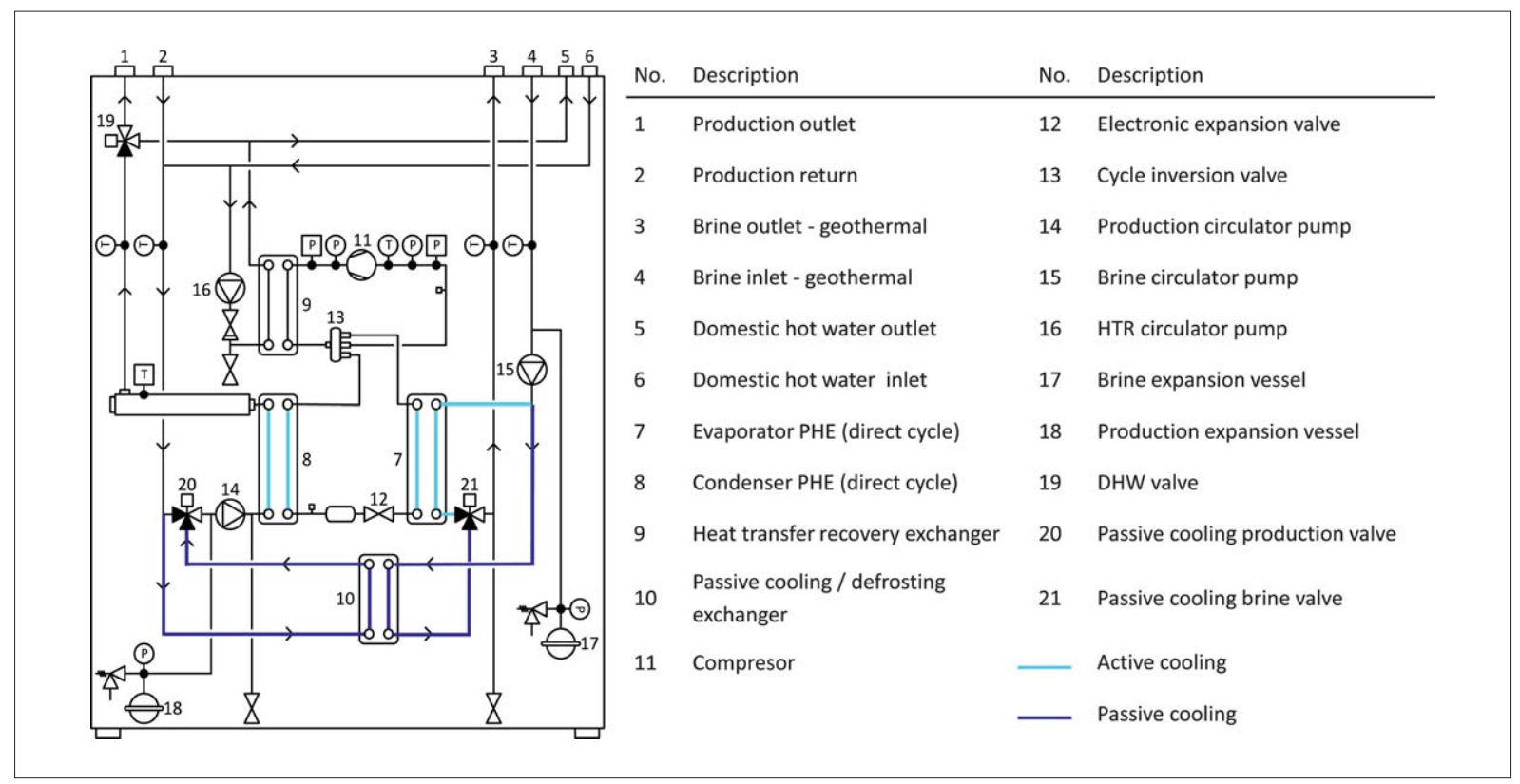

Figure 4: Internal schematic of an inverter geothermal heat pump with passive/active cooling option (according to Ecoforest ecoGEO B4 HTR model) (www.ecoforest.es)

source and the consumer system. Furthermore, in geothermal applications the primary brine circuit is separated from a secondary cooling circuit by a plate heat exchanger (PHE) inside the heat pump (see Figure 4). A temperature rise between inlet and outlet flow through a PHE is usually between $1.5-2.0{ }^{\circ} \mathrm{C}$ due to heat loss, which suggests that passive cooling can have only modest potential under these conditions.

Also, passive cooling is an extremely inert system and therefore it is necessary to work continuously throughout the cooling season to secure comfort, which requires a stable geothermal source temperature over a long period of time. On the other hand, active cooling involves the operation of a heat pump compressor in a classical vapour compression refrigeration cycle. Heat energy from the building together with the compression heat is rejected to the geothermal source. The outlet water temperature is usually set in the range of $7-10^{\circ} \mathrm{C}$ and it is distributed into the interior via fan coils. Such a system presumes a quick response to consumer cooling needs due to its lower outlet temperature, and it operates with less working hours on a yearly basis compared to passive cooling.

\subsection{Case study - three analysed locations and geological environment}

The ground thermal response test and the determination of the steady-state heat rejection rates of the coaxial heat exchanger system were performed at the three locations in Zagreb. One location is at the Faculty of geology, mining and petroleum engineering (abbreviated in paper as RGN), serving as a testing heat exchanger for students. Other two test locations were private family houses (abbreviated in paper as MBM and TVK), where measurements were carried out as part of mechanical engineering design phase and shallow geothermal research.

In each case, boreholes were cemented with a mixture of thermoactive cement and a water to ensure flexible adherence and a good heat transfer between outer pipe and ground. Normed thermal conductivity of such spe-

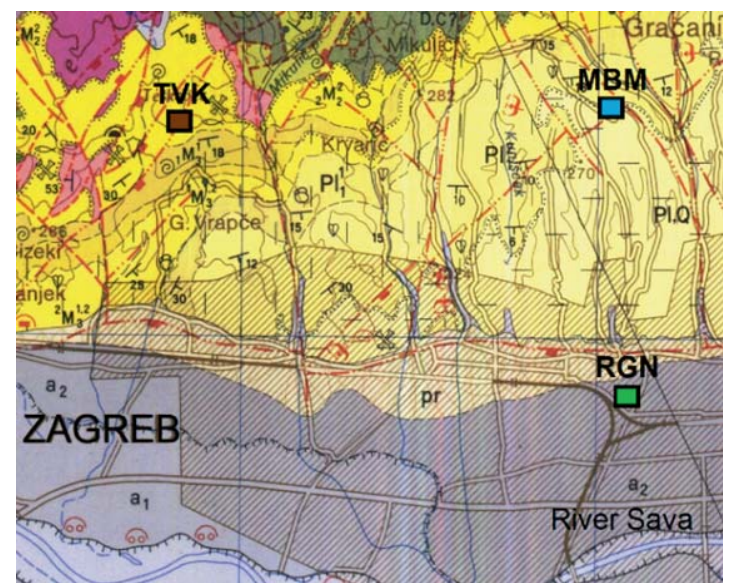

Legend for geology map:

a - alluvium: gravels, sands and clays; $\mathrm{a}_{1}$ - the lowest terrace: gravels, sands and clays to a lesser extent; $\mathrm{a}_{2}$ - middle terrace: gravels and sands; $\mathrm{pr}$ - proluvium: gravels, sands and clays; 1 - clayey silt; lb - marshy loes: silty clays; Pl,Q - gravels, sands and clays; $\mathrm{Pl}_{1}{ }^{1}-$ marls, marly clays, sands to a lesser extent, sandstones, gravels and conglomerates (Lower Pontian); ${ }_{2} \mathrm{M}_{3}^{1,2}-$ lime marls, sands to a lesser extent, sandstones, gravels and conglomerates (Upper Pannonian); ${ }_{2} \mathrm{M}_{2}{ }^{2}-$ limestones, sandstones, lime and clayey marls (Upper Tortonian)

Figure 5: Geology map for the city of Zagreb and three analysed locations (Šikić et al. 1978) 
cialized mixtures is usually in a range of $2.0-2.2 \mathrm{~W} / \mathrm{m}^{\circ} \mathrm{C}$, while commonly used clay and ordinary cement blends typically have a value of $1.0-1.5 \mathrm{~W} / \mathrm{m}^{\circ} \mathrm{C}$ (Kurevija, 2017).

A detailed geological setting of the city of Zagreb and the corresponding research locations can be seen in Figure 5, according to Šikić et al. (1978). The Zagreb area consists of Middle and Upper Pleistocene sediments, where lateral changes of gravel, silt, sand and clay are frequent, and Holocene sediments which consist of yellow-brown gravel, sand and limestone pebbles. The analysed locations TVK and MBM are set in Lower Pontian, Upper Pannonian and Upper Tortonian areas with dominant clay. The RGN location is set near the Zagreb aquifer boundaries in alluvium and the lowest terrace, characterized with changes of gravel, sands and clay to a different extent. The thin aquifer layer is set at the depth between 6 and $12 \mathrm{~m}$ from the surface. The geothermal gradient at the Zagreb city area is $5.5{ }^{\circ} \mathrm{C}$ per $100 \mathrm{~m}$ of depth (Kurevija, 2014).

\section{Results}

\subsection{Determination of thermogeological ground properties analysing first TRT power step}

Extended thermal response tests were carried out on the three different locations described in section 3.3. Test duration time, step periods and rejected power vary on all locations. As seen in Figure 2, the first period of TRT is used to determine the thermal conductivity of the ground, effective borehole temperature and equivalent thermal resistance. Consequential steps are used to determine rejected heat rates for a heat exchanger at steady state heat transfer conditions.
Each TRT procedure started with the sole circulation of borehole fluid without heating power to determine the effective ground temperature. On all three locations, the temperature stabilized at $14{ }^{\circ} \mathrm{C}$ after $15-30 \mathrm{~min}$ of circulation. The surface mean annual air temperature in the city of Zagreb is $12.1{ }^{\circ} \mathrm{C}$ while undisturbed ground temperature occurs at a depth of $10 \mathrm{~m}$ with a value of 13.1 ${ }^{\circ} \mathrm{C}$ (Kurevija, 2010). After the initial period, the classical thermal response test was performed. Locations RGN and TVK had an initial duration of $72 \mathrm{hr}$, while the MBM location had a duration of $48 \mathrm{hr}$ which is a preferably lower-end value (Javed, 2011, Zhang et al. 2014).

To determine the ground thermal conductivity, it is important to determine the transition period from unsteady state heat transfer to the semi-steady state heat transfer (as seen in Figure 2). The usual method is by using the formula with a $10 \%$ error, $\alpha t / r^{2}>5$ (Gehlin, 2002), which contains a value of thermal diffusivity $\alpha$ in the nominator, which is assumed by the ground composition from the drilling data. Since this is not the exact value, this method of determining the duration of the transition period can cause an error in interpretation, especially for heterogeneous ground.

A much more precise method is presented in this research, based on the derivation curve principle which is often used in the oil industry during pressure build-up well testing. The principle of this method is to monitor a segment of change in the borehole fluid temperature versus some small segment of time. The duration of this segment is chosen to be 10 minutes, as this is roughly the time of one flow cycle trough the coaxial heat exchanger. This method could be interpreted similarly to a real derivation curve. The derivative of a point on a certain curve is the tangent on that curve. By looking at a change of $\Delta \mathrm{T}$ vs. $\Delta \mathrm{t}$ on a curve, the line that connects these two

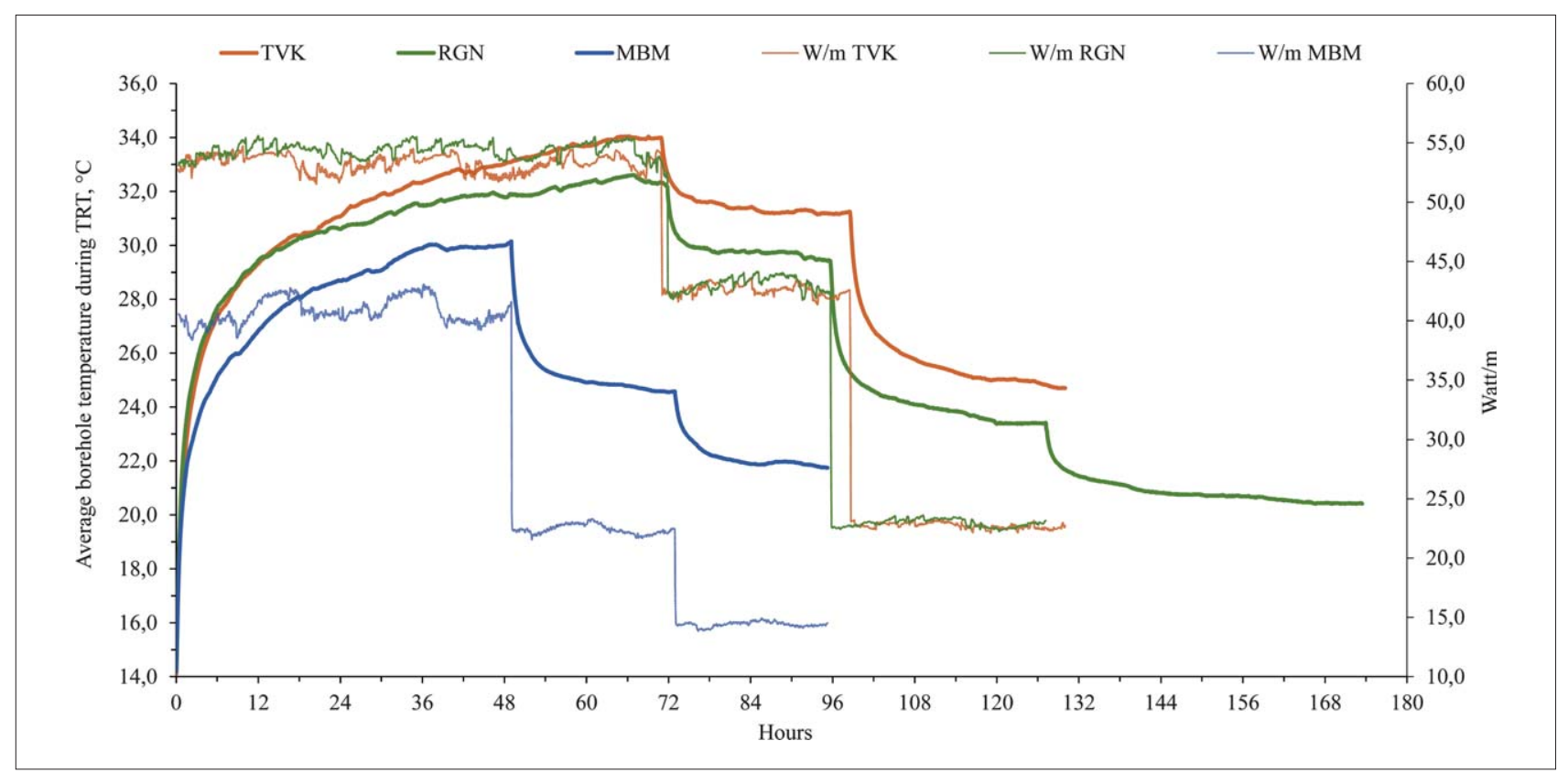

Figure 6: Recorded average borehole temperature and heat power during SSTRST at three analysed locations 


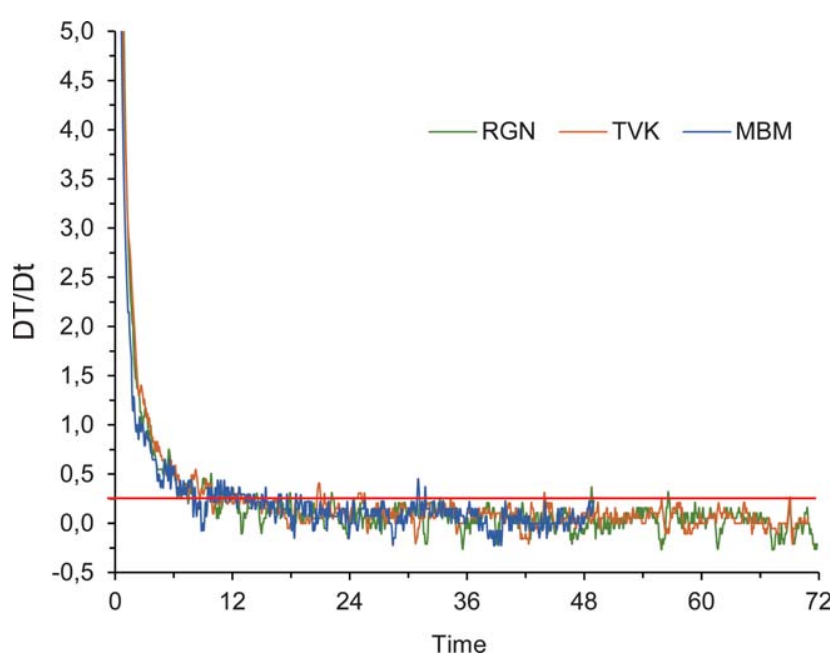

Figure 7: Determination of the transition period from unsteady state to semi-steady state heat transfer by principle of derivation curve

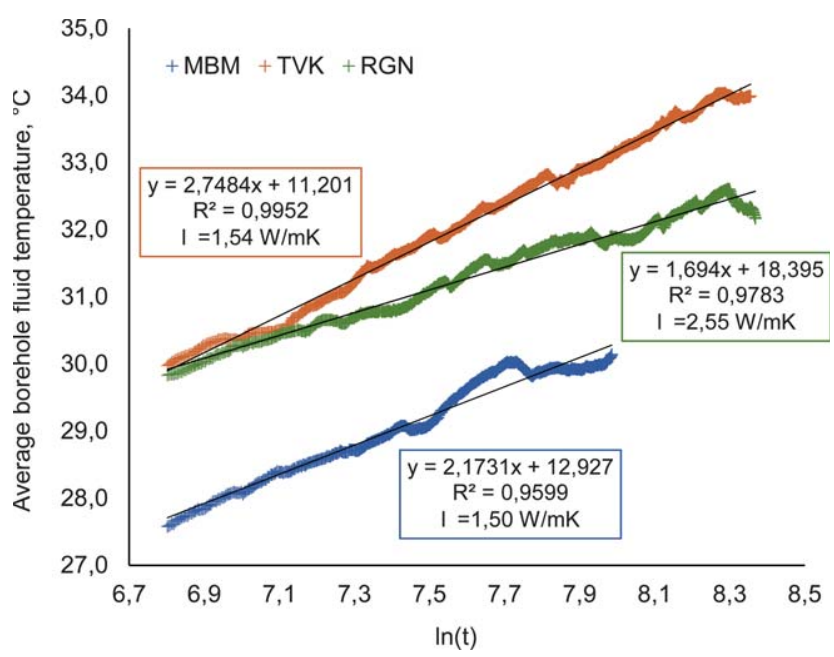

Figure 8: Determination of ground thermal conductivity during the first step interval for three locations

points is the secant. If $\Delta \mathrm{T}$ versus $\Delta \mathrm{t}$ is small enough, then the secant and the tangent fall almost in the same line.

As seen in Figure 7, after a period of $15 \mathrm{hr}$, the temperature change for all three locations fell below 0.25 ${ }^{\circ} \mathrm{C} / 10 \mathrm{~min}$, which is arbitrarily chosen to be a satisfactory value. Deviation of the curves in Figure 7 is solely dependent on day and night time power fluctuations from an electricity grid. Therefore, the period after $15 \mathrm{hr}$ on all three locations will be used for interpretation during first power step.

In order to determine the coefficient of ground thermal conductivity, the mean temperature of the circulating fluid from the first step must be drawn as a function of the natural logarithm of time $\ln (\mathrm{t})$. After the electric heater is switched on, the average temperature in the borehole converter starts to grow in the function of the thermal conductivity of the ground. The ground thermal conductivity coefficient is determined graphically from the part of the collected data where there is a linear tem-
Table 1: Technical data and determined thermogeological properties for the three analysed locations

\begin{tabular}{|c|c|c|c|c|c|}
\hline \multicolumn{6}{|c|}{ Location 1 - RGN Faculty } \\
\hline \multicolumn{4}{|c|}{ Properties } & Value & Unit \\
\hline \multicolumn{3}{|c|}{ Undisturbed ground temperature } & $\mathrm{Ti}^{\top}$ & 14,1 & ${ }^{\circ} \mathrm{C}$ \\
\hline \multicolumn{3}{|c|}{ Outer pipe diameter, SDR11 } & Do ${ }^{\top}$ & 63,0 & $\mathrm{~mm}$ \\
\hline \multicolumn{3}{|c|}{ Inner pipe diameter, SDR11 } & Di & 32,0 & $\mathrm{~mm}$ \\
\hline \multicolumn{3}{|c|}{ Borehole length $(3 \times 33,3 \mathrm{~m})$} & $\mathrm{L}$ & 100,0 & $\mathrm{~m}$ \\
\hline \multicolumn{3}{|c|}{ Presumed diffusivity } & $\alpha$ & 0,100 & $\mathrm{~m}^{2} / \mathrm{d}$ \\
\hline \multicolumn{3}{|c|}{ Borehole resistance, 1 st step } & $\mathrm{Rb}$ & 0,191 & $\mathrm{~m}^{\circ} \mathrm{C} / \mathrm{W}$ \\
\hline \multicolumn{3}{|c|}{ Fluid flow } & W & 0,42 & $1 / \mathrm{s}$ \\
\hline \multicolumn{6}{|c|}{ Skin properties } \\
\hline Step & Skin & Unit & & $\Delta \mathrm{T}$ skin & Unit \\
\hline 1. & 2,19 & - & & 7,4 & ${ }^{\circ} \mathrm{C}$ \\
\hline 2. & 2,41 & - & & 6,5 & ${ }^{\circ} \mathrm{C}$ \\
\hline 3. & 3,07 & - & & 4,4 & ${ }^{\circ} \mathrm{C}$ \\
\hline 4. & 3,32 & - & & 3,1 & ${ }^{\circ} \mathrm{C}$ \\
\hline
\end{tabular}

Ground description

Clay with thin saturated gravel layer (at depth 6-12 m)

\begin{tabular}{|c|c|c|c|c|c|}
\hline \multicolumn{6}{|c|}{ Location 2 - Family house TVK } \\
\hline \multicolumn{4}{|c|}{ Properties } & Value & Unit \\
\hline \multicolumn{3}{|c|}{ Undisturbed ground temperature } & $\mathrm{Ti} \boldsymbol{\nabla}$ & 14,1 & ${ }^{\circ} \mathrm{C}$ \\
\hline \multicolumn{3}{|c|}{ Outer pipe diameter, SDR11 } & Do ${ }^{\top}$ & 63,0 & $\mathrm{~mm}$ \\
\hline \multicolumn{3}{|c|}{ Inner pipe diameter, SDR11 } & $\mathrm{Di} \nabla$ & 40,0 & $\mathrm{~mm}$ \\
\hline \multicolumn{3}{|c|}{ Borehole length $(2 \times 50,0 \mathrm{~m})$} & $\mathrm{L}^{\nabla}$ & 100,0 & $\mathrm{~m}$ \\
\hline \multicolumn{3}{|c|}{ Presumed diffusivity } & $\alpha$ & 0,050 & $\mathrm{~m}^{2} / \mathrm{d}$ \\
\hline \multicolumn{3}{|c|}{ Borehole resistance, 1st step } & $\mathrm{Rb}$ & 0,134 & $\mathrm{~m}^{\circ} \mathrm{C} / \mathrm{W}$ \\
\hline \multicolumn{3}{|c|}{ Fluid flow } & $\mathrm{w}$ & 0,48 & $1 / \mathrm{s}$ \\
\hline \multicolumn{6}{|c|}{ Skin properties } \\
\hline Step & Skin & Unit & & $\Delta \mathrm{T}$ skin & Unit \\
\hline 1. & 1,04 & - & & 5,7 & ${ }^{\circ} \mathrm{C}$ \\
\hline 2. & 1,15 & - & & 5,1 & ${ }^{\circ} \mathrm{C}$ \\
\hline 3. & 1,64 & - & & 3,8 & ${ }^{\circ} \mathrm{C}$ \\
\hline
\end{tabular}

Ground description

Dominantly clay

\begin{tabular}{lrrr}
\multicolumn{3}{c}{ Location 3 - Family house MBM } \\
\hline Properties & & Value & Unit \\
\hline Undisturbed ground temperature & $\mathrm{Ti}^{\boldsymbol{}}$ & 14,1 & ${ }^{\circ} \mathrm{C}$ \\
Outer pipe diameter, SDR11 & $\mathrm{Do}^{\boldsymbol{}}$ & 63,0 & $\mathrm{~mm}$ \\
Inner pipe diameter, SDR11 & $\mathrm{Di}^{\boldsymbol{}}$ & 40,0 & $\mathrm{~mm}$ \\
Borehole length (3×33,3 m) & $\mathrm{L}$ & 100,0 & $\mathrm{~m}$ \\
Presumed diffusivity & $\alpha$ & 0,050 & $\mathrm{~m}^{2} / \mathrm{d}$ \\
Borehole resistance, 1st step & $\mathrm{Rb}$ & 0,165 & $\mathrm{~m}^{\circ} \mathrm{C} / \mathrm{W}$ \\
Fluid flow & $\mathrm{w}$ & 0,34 & $1 / \mathrm{s}$
\end{tabular}

Skin properties

\begin{tabular}{lcccr} 
Step & Skin & Unit & $\Delta$ T skin & Unit \\
\hline 1. & 1,15 & - & 5,0 & ${ }^{\circ} \mathrm{C}$ \\
2. & 1,66 & - & 3,9 & ${ }^{\circ} \mathrm{C}$ \\
3. & 2,12 & - & 3,2 & ${ }^{\circ} \mathrm{C}$
\end{tabular}

Ground description

Dominantly clay 
perature dependence versus the natural logarithm of time (semi-steady state heat transfer). As seen in Figure $\mathbf{8}$, the selected curves were fitted with the LINEST function in MS Excel, which calculates the statistics for a line by using the least squares method to calculate a straight line that best fits the recorded data, and then returns an array that describes the line.

According to Gehlin (2002), the obtained slope of the line can then be used to determine the ground thermal conductivity coefficient using Equation 6. Both locations placed in dominantly clay environment show similar values, $1.50 \mathrm{~W} / \mathrm{m}^{\circ} \mathrm{C}$ for $\mathrm{MBM}$ and $1.54 \mathrm{~W} / \mathrm{m}^{\circ} \mathrm{C}$ for TVK. The RGN location shows much higher ground thermal conductivity, $2.55 \mathrm{~W} / \mathrm{m}^{\circ} \mathrm{C}$, due to the fact that the permeable groundwater layer contributes with additional convective heat energy transfer, besides conduction in the impermeable clay layers.

Using Equations 7, 8 and 9 with the obtained ground thermal conductivity, it is possible to calculate the equivalent borehole resistance and subsequently the skin value and skin temperature difference. The calculated values are presented in Table 1, along with other technical data related to each coaxial system.

\subsection{Determination of passive and active cooling heat rejection rates by applying novel step test}

After the classic Thermal Response test was performed on all locations, an additional step TRT was implemented, according to the principle shown in Figure 2. In this type of test, power is reduced in the second step and the temperature is monitored until it stabilizes, or when the so-called steady state heat transfer occurs. After the stabilization of the temperature, the power condition is again reduced until the temperature again reaches approximately constant values. The procedure is repeated three to four times with the recommendation that the maximum power condition is two to three times higher than the minimum.

Furthermore, the first step from which thermal conductivity has been calculated could be extended using the linear equation (from Figure 8) up to an $150 \mathrm{hr}$ time span (dotted lines in Figure 10).

This could substitute the long and unnecessary TRT performing time in the first step, as the temperature grows linearly vs. logarithmic time. However, after an arbitrarily chosen time span of $150 \mathrm{hr}$, there is very little change in temperature over longer periods, so this condition could also be treated as a semi-steady-state heat flow regime in further analysis.

The collected data from the three locations by the SSTRS test is presented in Table 2. Each of the performed step is defined with its stabilized temperature where steady-state heat transfer is achieved. As an additional zero power step, initial temperature conditions are introduced.

This method can give reliable information on the relation between working conditions of the heat pump sys-
Table 2: Collected data by SSTRST for the three analysed locations

\begin{tabular}{llccccc}
\multicolumn{7}{c}{ Location 1 - RGN Faculty } \\
\hline & $\begin{array}{l}\text { heat } \\
\text { flow }\end{array}$ & $\begin{array}{c}\text { TRT heat } \\
\text { power }\end{array}$ & $\begin{array}{c}\text { TRT } \\
\text { time }\end{array}$ & $\begin{array}{c}\text { Cooling } \\
\text { cycle }\end{array}$ & $\begin{array}{c}\text { Cooling } \\
\text { cycle }\end{array}$ & $\begin{array}{c}\text { Rejected } \\
\text { to ground } \\
\text { step }\end{array}$ \\
regime & $\mathrm{W} / \mathrm{m}$ & $\mathrm{hr}$ & $\mathrm{EST}^{1}$ & $\mathrm{LST}^{2}$ & $\mathrm{kWh}$ \\
\hline 1. & US+SSS & 54,4 & 71,8 & 30,4 & 32,8 & 389,1 \\
1.a & SSS+SS & 54,4 & 150,0 & 32,3 & 35,4 & 815,7 \\
2. & SS & 43,1 & 23,8 & 28,2 & 30,6 & 102,7 \\
3. & SS & 23,0 & 31,5 & 22,7 & 24,0 & 72,3 \\
4. & SS & 14,7 & 46,3 & 20,0 & 20,8 & 68,1 \\
5. & IS & 0,0 & 0,0 & 14,1 & 14,1 & 0,0
\end{tabular}

\begin{tabular}{|c|c|c|c|c|c|c|}
\hline \multicolumn{7}{|c|}{ Location 2 - Family house TVK } \\
\hline & $\begin{array}{l}\text { heat } \\
\text { flow }\end{array}$ & $\begin{array}{l}\text { TRT heat } \\
\text { power }\end{array}$ & $\begin{array}{l}\text { TRT } \\
\text { time }\end{array}$ & $\begin{array}{c}\text { Cooling } \\
\text { cycle }\end{array}$ & $\begin{array}{l}\text { Cooling } \\
\text { cycle }\end{array}$ & $\begin{array}{l}\text { Rejected } \\
\text { to ground }\end{array}$ \\
\hline step & regime & $\mathrm{W} / \mathrm{m}$ & $\mathrm{hr}$ & $\mathrm{EST}^{1}$ & $\mathrm{LST}^{2}$ & $\mathrm{kWh}$ \\
\hline 1. & US+SSS & 53,3 & 70,9 & 32,7 & 35,2 & 377,8 \\
\hline 1.a & $\mathrm{SSS}+\mathrm{SS}$ & 53,3 & 150,0 & 34,9 & 37,5 & 799,0 \\
\hline 2. & SS & 42,6 & 27,7 & 30,1 & 32,2 & 117,8 \\
\hline 3. & SS & 22,7 & 31,4 & 24,2 & 25,2 & 71,4 \\
\hline 4. & IS & 0,0 & 0,0 & 14,1 & 14,1 & 0,0 \\
\hline \multicolumn{7}{|c|}{ Location 3 - Family house MBM } \\
\hline & $\begin{array}{l}\text { heat } \\
\text { flow }\end{array}$ & $\begin{array}{l}\text { TRT heat } \\
\text { power }\end{array}$ & $\begin{array}{l}\text { TRT } \\
\text { time }\end{array}$ & $\begin{array}{l}\text { Cooling } \\
\text { cycle }\end{array}$ & $\begin{array}{c}\text { Cooling } \\
\text { cycle }\end{array}$ & $\begin{array}{l}\text { Rejected } \\
\text { to ground }\end{array}$ \\
\hline step & regime & $\mathrm{W} / \mathrm{m}$ & hr & $\mathrm{EST}^{1}$ & $\mathrm{LST}^{2}$ & $\mathrm{kWh}$ \\
\hline 1. & $\mathrm{US}+\mathrm{SSS}$ & 40,8 & 49,0 & 28,4 & 31,8 & 199,9 \\
\hline 1.a & $\mathrm{SSS}+\mathrm{SS}$ & 40,8 & 150,0 & 31,0 & 34,4 & 611,9 \\
\hline 2. & SS & 22,4 & 23,9 & 23,7 & 25,5 & 53,6 \\
\hline 3. & SS & 14,4 & 22,3 & 21,2 & 22,3 & 32,2 \\
\hline 4. & IS & 0,0 & 0,0 & 14,1 & 14,1 & 0,0 \\
\hline
\end{tabular}

tem and steady-state entering source temperature from the bore field in a passive and active cooling regime. This means that for a certain heat rejection rate, temperature in the borehole will stabilize and a system can work for a longer period of time without an additional rise in temperature.

By setting the steady-state temperature in each of the steps as separate points, it is possible to construct the heat rejection cooling diagram $(\mathrm{W} / \mathrm{m})$ as a function of the desired inlet temperature (EST - Entering source temperature) to the heat pump, as seen in Figure 9.

If the fluid temperature of $18^{\circ} \mathrm{C}$ is set in the cooling cycle as a minimum permissible on the outlet of the heat exchanger during long-term operation, then it can be seen in Figure 9. The EST equations that passive cooling yields are only $6-11 \mathrm{~W} / \mathrm{m}$ depending on the location.

Inclined coaxial heat exchangers are usually connected as two in series, making it a $2 * 50 \mathrm{~m}$ or $100 \mathrm{~m}$ cumulative borehole in length. This means that the passive cooling rejection rate will be only $0.6-1.1 \mathrm{~kW}$ per one borehole of $100 \mathrm{~m}$.

In addition, as stated in section 3.2., real projects must divide the primary geothermal circuit from the interior distribution circuit by a plate heat exchanger. With an additional temperature rise of $1.5{ }^{\circ} \mathrm{C}$ at the heat ex- 


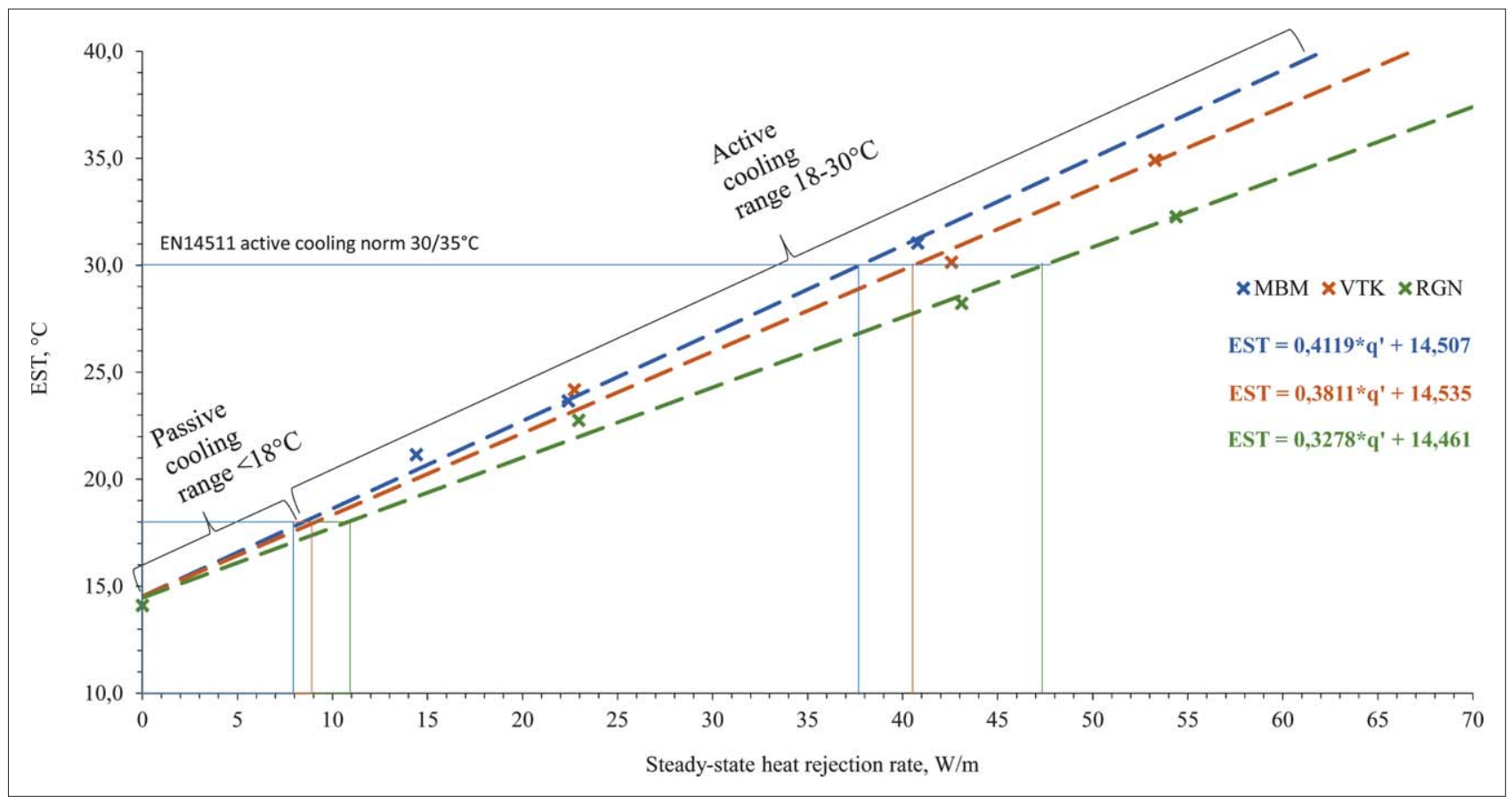

Figure 9: Steady-state heat rejection rate versus outlet temperature from the coaxial heat exchanger for passive and active cooling range

changer, real passive cooling rejection rate would then be merely $0.48-0.62 \mathrm{~kW}$ per $100 \mathrm{~m}$. Considering the current drilling and completion costs of coaxial borehole heat exchangers of $40 € / \mathrm{m}$, this is certainly not a viable techno-economical option to consider.

Using a geothermal inverter heat pump described in section 3.2., with an option of both passive and active cooling, is an economically preferable choice. In the period of the late spring and early summer months, a borehole field could work only on passive heat exchange. When building cooling loads surpass the coaxial borehole heat rejection rate for a certain temperature range, the heat pump will automatically switch to an active cooling regime and the use of the compressor.

This would raise the borehole temperature significantly during the summer months in a peak load period. The economical limit is considered to be $30 / 35{ }^{\circ} \mathrm{C}$ regime at the geothermal source. This temperature is also an EN14511 norm testing value for a heat pumps to compare different EER values in active cooling. Considering this limit and applying steady-state rejection rates equations from Figure 9., active cooling yield would be in the range of $3.8-4.7 \mathrm{~kW}$ per $100 \mathrm{~m}$ borehole for the analysed locations. It is important to point out that this heat rejected to the ground consists of the building cooling loads and of the compressor waste heat.

When thermogeological properties of the ground are determined by classical TRT, i.e. thermal conductivity and diffusivity, borehole resistance and skin value, then the extended SSTRS test could be simulated by fitting the heat rejection steps with an exponential integral function from Equation 14.
For each of the measured borehole step temperatures shown in Figure 6, a fitted line is constructed with the $E i$ function. The results are presented in Figure 10. For most of the steps on three analysed locations, there is very good data agreement, except for the RGN location and the $4^{\text {th }}$ small power step. This could be explained with surface interference heat gain, as the testing location has longer collector pipes from the boreholes to the TRT apparatus and measurement was performed during the summer months.

\section{Conclusion}

The results presented by the novel method of steadystate thermal response test (SSTRST) show that it is not necessarily applicable only to determine the thermal properties of the ground. Data obtained from measurements can be used to optimize the design of the borehole heat exchanger field. Such systems in practice are often unnecessarily oversized as the result of the insecurity factor, or undersized as a result of poor engineering design and an inadequate understanding of thermogeological properties of the ground. In both cases, this is negatively reflected on the economic viability of the project itself. From this perspective, long-term and advanced ground thermal response measurements are disbursed, as it will ensure the longevity of the system and the knowledge of the borehole temperature evolution during the summer months. Therefore, this research proves that coaxial heat exchangers are not suitable for a solely passive cooling option of the building, due to large borehole length needed to obtain any meaningful amount of cool- 

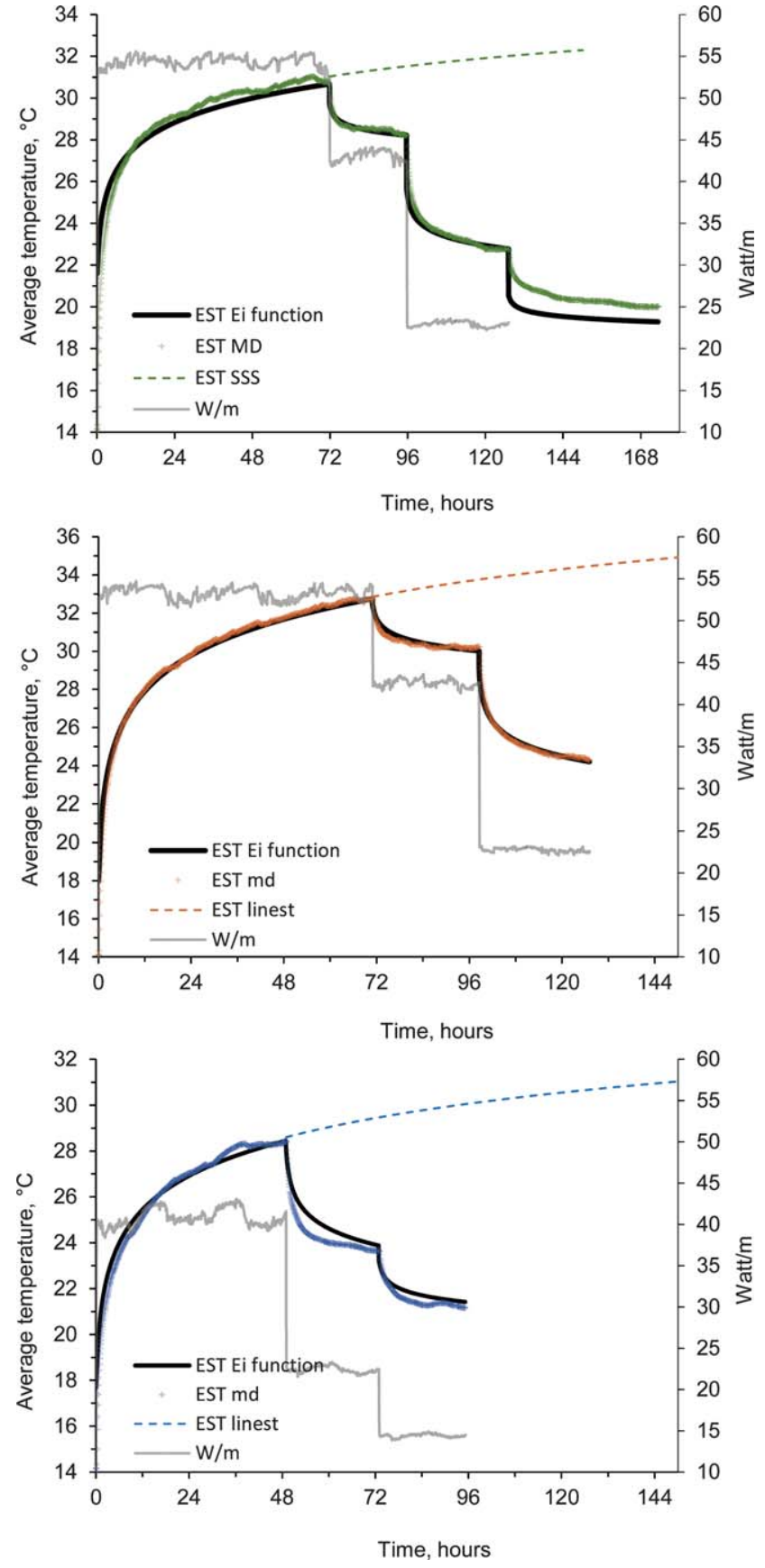

Figure 10: Fitting of measured temperature data with ILS exponential integral function

ing load. Therefore, such geothermal exchange systems always need to be designed with an 0active cooling option, which presumes heat pump compressor operation.

\section{Nomenclature and abbreviations}

$\begin{array}{ll}c & \text { specific heat }\left(\mathrm{J} / \mathrm{kg}{ }^{\circ} \mathrm{C}\right) \\ E i & \text { exponential integral } \\ r & \text { radius around line source } \\ r_{w} & \text { wellbore radius }(\mathrm{m}) \\ R_{b} & \text { equivalent borehole resistance }\left({ }^{\circ} \mathrm{C} \mathrm{m} / \mathrm{W}\right)\end{array}$

$t \quad$ time (h)

$T_{i} \quad$ undisturbed mean ground temperature $\left({ }^{\circ} \mathrm{C}\right)$

$T \quad$ borehole fluid temperature $\left({ }^{\circ} \mathrm{C}\right)$

$T(r, t) \quad$ temperature field with time and radius $\left({ }^{\circ} \mathrm{C}\right)$

$q$, heat power $(\mathrm{W} / \mathrm{m})$

$\alpha$ thermal diffusivity $\left(\mathrm{m}^{2} / \mathrm{h}\right)$

$\gamma \quad$ Euler's constant

$\lambda$ thermal conductivity of ground $\left(\mathrm{W} / \mathrm{m}{ }^{\circ} \mathrm{C}\right)$

$\rho \quad$ density of the ground $\left(\mathrm{kg} / \mathrm{m}^{3}\right)$

EER Energy Efficiency Ratio

EST Entering Source Temperature to the heat pump

IS Initial state

LST Leaving Source Temperature from the heat pump

MD Measured

SS Steady-state

SSS Semi-steady state

SSTRST Steady State Thermal Response Step Test

TRT Thermal Response Test

USS Unsteady-state

\section{References}

Zhang, C., Guo, Z., Liu, Y., Cong, X., Peng, D. (2014): Renewable and Sustainable Energy Reviews. 40, 851-867.

Matthews, C.S., Russell D.G. (1967): Pressure Buildup and Flow Tests in Wells, Society of Petroleum Engineers of AIME, SPE.

Carslaw, H. S., \& Jaeger, J. C., (1946): Conduction of heat in solids. Oxford, UK, Claremore Press.

Narasimhan, T.N. (1999) Fourier's heat conduction equation: history, influence and connections, Geophysics, 37, 151-172

Sass, I., Lehr, C. (2011): Improvements on the thermal response test evaluation applying the cylinder source theory, Proceedings of the thirty-sixth Workshop on Geothermal Reservoir Engineering, Stanford University, California, SGP-TR-191.

Lee, J. (1982): Well Testing, Society of Petroleum Engineers of AIME, SPE.

Gehlin, S. (2002): Thermal Response test: Method development and evaluation, Lulea University of Technology, PhD dissertation

Stewart, G., (2011): Well test design \& analysis, PennWell, Tulsa, USA, $1545 \mathrm{p}$.

Kurevija, T., Macenić, M., Borović, S. (2017): Impact of grout thermal conductivity on the long-term efficiency of the ground-source heat pump system, Sustainable Cities and Society 31, 1-11.

Šikić, K., Basch, O., Šimunić, A. (1978): Basic geological map of SFRJ. Zagreb, Croatian Geological Survey.

Kurevija, T., Vulin, D., Macenić, M. (2014): Impact of geothermal gradient on ground source heat pump system modeling, Rudarsko-geološko-naftni zbornik, 28, 39-45.

Kurevija, T., Vulin, D. (2010): Determining undisturbed ground temperature as part of shallow geothermal resources assessment, Rudarsko-geološko-naftni zbornik, 22, 27-36. 
Javed, S., Spitler, J., Fahlén, P. (2011): An experimental investigation of the accuracy of thermal response tests used to measure ground thermal properties. ASHRAE Transactions, $117,1,13-21$.
Internet sources:

Heat pump technical data on Ecoforest company webpages, www.ecoforest.es

\section{SAŽETAK}

\section{Određivanje potencijala pohranjivanja toplinske energije koaksijalnim bušotinskim izmjenjivačem topline kod pasivnoga i aktivnoga hlađenja primjenom nove metode „step” testa toplinskoga odaziva tla}

Tipski i prošireni test toplinskoga odaziva tla (TRT) izveden je na koaksijalnim izmjenjivačima topline na trima različitim lokacijama u Zagrebu. Tipskim testom toplinskoga odaziva određena su termogeološka svojstva tla i bušotinski otpor. Zbog različitosti geoloških profila toplinska vodljivost tla varira. Provedena su i eksperimentalna mjerenja „step” testom toplinskoga odaziva tla (SSTRST) u svrhu određivanja potencijala pohrane toplinske energije kod pasivnoga i aktivnoga hlađenja prilikom ustaljenoga stanja prijenosa topline. Rezultati su pokazali potencijal pohrane toplinske energije u tlo između 8 i 11 vata po metru bušotine, upućujući na nemogućnost pasivnoga hlađenja koaksijalnim izmjenjivačem topline. Nadalje, dizalice topline u režimu pasivnoga hlađenja koriste se pločastim izmjenjivačem, na kojemu dolazi do dodatnoga temperaturnog pada za otprilike $1,5{ }^{\circ} \mathrm{C}$. Stoga je mogućnost pohrane toplinske energije još i manja kod realnih projekata s pasivnim hlađenjem. Koaksijalni izmjenjivači topline uvijek bi morali biti projektirani za rad u aktivnome režimu hlađenja gdje kompresor dizalice topline radi u klasičnome parnom kompresijskom ciklusu.

\section{Ključne riječi}

plitka geotermalna energija, termogeologija, bušotinski izmjenjivač topline, površinska toplinska crpka

\section{Author's contribution:}

Tomislav Kurevija initializing idea and leading the research, conducting TRT field measurements at all locations, processing data from TRT logger and perform all calculations in Excel, writing paper and coordinating. Marija Macenić compiled Methods section, calculations related to skin and borehole resistance, fitting data curves with ILS, helped with formulating text Kristina Strpić helped with field TRT measurement at the RGN location, interpreting step tests and heat rejection rates, formulating text. 